\title{
MOTIVASI PEMBELAJARAN DARING DALAM MENINGKATKAN PROSES PEMBELAJARAN UNTUK PARA TENAGA PENDIDIK
}

\author{
Syarifah Ida Farida ${ }^{1}$, Teguh Yuwono ${ }^{2}$, Yusep Prihanto ${ }^{3}$, R.Chepi Safei Jumhana ${ }^{4}$, \\ Lucia Maduningtias ${ }^{5}$ \\ ${ }^{1,2,3,4,5)}$ Program Studi Manajemen, Fakultas Ekonomi, Universitas Pamulang \\ e-mail:dosen01477@unpam.ac.id
}

\begin{abstract}
Abstrak
Tujuan pengabdian kepada masyarakat ini untuk memberikan pelatihan dan sharing ilmu mengenai Motivasi Pembelajaran Daring dalam Meningkatkan Proses Pembelajaran untuk Para Tenaga Pendidik di SMPN 12 Tangerang Selatan. Metode yang digunakan ada beberapa tahap diantaranya tahap persiapan, yang meliputi survey awal, pemantapan dan penentuan lokasi dan sasaran. Setelah survey maka ditentukan lokasi pelaksanaan dan sasaran peserta kegiatan. Tahap berikutnya yaitu tahap pelaksanaan Pengabdian Kepada Masyarakat. Tahap ini akan diberikan materi pelatihan mengenai bagaimana cara memberikan motivasi kepada para murid di Sekolah Menengah Pertama Negeri 12 Tangerang Selatan dalam Pembelajaran Daring untuk meningkatkan Proses Pembelajaran. Hasil dari Pengabdian Kepada Masyarakat adalah tenaga pendidik di SMPN12 Tangerang Selatan menjadi lebih termotivasi dalam memberikan Proses Pembelajaran kepada murid-muridnya dengan fikiran yang positif dan kreativitas sehingga ruang guru bukan hanya di kelas tetapi di dalam hati dan dimana saja (out of the box). Dengan adanya Pandemi Covid-19 menuntut tenaga pendidik/guru harus lebih rajin, kreatif dan inovatif. Sehingga tetap bisa berjalan pembelajaran dengan nyaman dan kondusif sesuai dengan capaian pembelajaran yang telah ditentukan masing-masing mata pelajaran di sekolah.
\end{abstract}

Kata kunci: Pelatihan, Pembelajaran, Daring

\begin{abstract}
The purpose of this community service is to provide training and knowledge sharing about Online Learning Motivation in Improving the Learning Process for Educators at SMPN 12 South Tangerang.The method used has several stages including the preparation stage, which includes the initial survey, strengthening and determining the location and target. After the survey, the location for the implementation and the target of the activity participants were determined. The next stage is the stage of implementing Community Service. At this stage, training materials will be given on how to motivate students at Junior High School 12 Tangerang Selatan in Online Learning to improve the Learning Process. The result of Community Service is the teaching staff at SMPN12 South Tangerang has become more motivated in providing the Learning Process to its students with positive thoughts and creativity so that the teacher room is not only in the classroom but inside and anywhere (out of the box). With the Covid-19 Pandemic, educators / teachers must be more diligent, creative and innovative. So that learning can still run comfortably and conducively in accordance with the learning outcomes that have been determined by each subject in the school.
\end{abstract}

Keywords: Training, Learning, Online

\section{PENDAHULUAN}

Di masa pandemi Covid-19 ini, semua aspek kehidupan berubah menjadi Kebiasaan Baru yang awalnya menurut orang lain tidak biasa, sekarang menjadi sesuatu kebiasaan baru contohnya dengan menggunakan masker setiap ke luar rumah dan harus mencuci tangan dengan air bersih, sabun atau handsanitizer. Hal ini diharuskan untuk terhindar dari virus Covid-19 yang bisa menular secara cepat dari orang ke orang, dari benda ke orang dengan sangat mudah. Oleh karena itu, pemerintah daerah menerapkan Pembatasan Sosial Berskala Besar (PSBB) di beberapa zona merah dan zona hitam. PSBB tujuannya untuk meminimalisir penularan virus Covid-19 dan menurunkan jumlah masyarakat yang sakit dengan membatasi kegiatan di luar rumah. 
Semua aspek kehidupan dari aktivitas bersama keluarga, sekolah dan lingkungan sekitarnya berubah 180 derajat dikarenakan Pandemi Covid-19. Salah satunya yang berubah hampir 360 derajat yaitu pendidikan di sekolah. Kegiatan proses belajar dan mengajar di sekolah dilakukan secara daring atau online, dimana dari dulu hingga sebelum pandemi covid-19 dilakukan secara luring atau offline. Sama halnya dengan Sekolah Menengah Pertama Negeri 12 Tangerang Selatan yang terletak di Jurang Mangu Tangsel yang harus mengikuti perintah dari Kementerian Pendidikan dan Kebudayaan Republik Indonesia bahwa semua seluruh sekolah, kampus, pesantren diharapkan melakukan aktivitas proses pembelajarannya secara daring. Hal ini menjadi tantangan terbaru untuk para Tenaga Pendidik dan Tenaga Kependidikan di Sekolah dan Pendidikan Tinggi.

Berdasarkan informasi dan data yang kami terima di Sekolah Menengah Pertama Negeri 12 Tangerang Selatan yang terdiri dari 50 tenaga pendidik mereka sudah merasa nyaman dengan proses pembelajaran daring tetapi belum tentu siswa atau muridnya merasa nyaman Hal ini membuat murid-murid dan orang tua merasa terbebani dengan adanya pembelajaran daring. Ada beberapa orang tua yang merasa bingung untuk membantu anaknya di rumah dalam memberikan pengarahan dalam memahami pembelajaran yang diberikan dari gurunya. Sehingga menuntut orang tua dan murid harus bisa memahami dan belajar menggunakan teknologi digital.

SMPN 12 Tangerang Selatan yang harus bisa memberikan yang terbaik kepada para tenaga pendidik, tenaga kependidikan dan murid serta masyarakat sekitar. Oleh karena itu, harus mendapatkan feedback atas proses pembelajaran yang telah diberikan oleh para pendidik. Dengan adanya pandemi Covid-19 ini membuat para tenaga pendidik memberikan pembelajaran yang bisa memudahkan para murid-muridnya mengerti, memahami dan menyenangkan di semua mata pelajaran. Ini merupakan tantangan baru untuk para tenaga pendidik dalam menghadapi dan membuat bahan ajar serta memberikan motivasi kepada para muridnya, Untuk itu dibutuhkan motivasi dalam memberikan pembelajaran yang kreatif dan inovatif dalam mentransfer ilmu dari tenaga pendidik ke murid dengan cara yang menyenangkan dan tidak terlalu membebankan orang tua dalam membantu anak-anaknya di rumah.

Pembelajaran online dilakukan dengan memanfaatkan teknologi khususnya internet. Pembelajaran online dilakukan dengan sistem belajar jarak jauh, dimana Kegiatan Belajar dan Mengajar (KBM) tidak dilakukan secara tatap muka. Pembelajaran dilakukan dengan menggunakan media, baik media cetak (modul) maupun non cetak (audio/video), komputer/internet, siaran radio dan televisi. (Yulianto \& Patria, 2011)

Pada pembelajaran online, peserta didik dapat menjadi kurang aktif dalam menyampaikan aspirasi dan pemikirannya, sehingga dapat mengakibatkan pembelajaran yang menjenuhkan. Seorang siswa yang mengalami kejenuhan dalam belajar akan memperoleh ketidakmajuan dalam hasil belajar. Oleh karena itu, diperlukan pendorong untuk menggerakkan siswa agar semangat belajar sehingga dapat memiliki prestasi belajar. (Raimbarizki, 2017). Semangat belajar dapat dimiliki dengan meningkatkan motivasi belajar. Motivasi belajar adalah sebuah penggerak atau pendorong yang membuat seseorang akan tertarik kepada belajar sehingga akan belajar secara terus-menerus. Motivasi yang rendah dapat menyebabkan rendahnya keberhasilan dalam belajar sehingga akan merendahkan prestasi belajar siswa. Oleh karena itu, dalam pengabdian kepada masyarakat ini akan memberikan pelatihan kepada para tenaga pendidik bagaimana cara meningkatkan motivasi belajar siswa pada pembelajaran online akibat pandemi Covid-19. (Raimbarizki, 2017)

\section{METODE}

Metode yang digunakan dengan cara pelatihan dan memberikan motivasi kepada para tenaga pendidik di SMPN 12 Tangerang Selatan. Adapun metode yang kita lakukan dimulai dari tahap persiapan sampai dengan pelaksanaan.

\section{Tahap Persiapan}

a. Survey Awal

Kami melakukan survey ke SMPN 12 Tangerang Selatan dipandu oleh pimpinan di sana untuk mengetahui bagaimana fasilitas dan jumlah dari tenaga pendidik di sana.

survei kami lakukan pada bulan September 2020 melalui kerjasama dengan pihak sekolah yang diwakili oleh Wakil Kepala Sekolah yaitu Ibu Hanum. 
Informasi yang kami butuhkan bisa kami dapatkan melalui ibu Hanum dan diberikan sesuai dengan data yang dibutuhkan.

b. Pemantapan dan penentuan lokasi dan sasaran.

Setelah melakukan survey dan mendapatkan informasi serta data dari pihak SMPN 12 Tangerang Selatan, maka kami menentukan waktu dan tema yang sesuai kebutuhan dari pihak sekolah.

Adapun sasaran yang kami tentukan untuk Pengabdian Kepada Masyarakat di SMPN 12 Tangerang Selatan yaitu Tenaga Pendidik sebanyak 25 dikarenakan adanya pandemi covid-19 jadi kami batasi menjadi 25 tenaga pendidik dengan mengikuti protokol kesehatan. Sedangkan sebenarnya total keseluruhan tenaga pendidik ada 50 orang.

Kami mendapatkan lokasi Pengabdian Kepada Masyarakat ini dikarenakan permintaan dari pihak sekolah untuk memotivasi tenaga pendidik di SMPN 12 Tangerang Selatan. Hal ini yang membuat kami termotivasi dalam mempersiapkan Pengabdian Kepada Masyarakat di SMPN 12 Tangerang Selatan. Selain itu, jarak tempat Pengabdian Kepada Masyarakat ini juga dekat dengan Universitas Pamulang yang terletak di Jurang Mangu Tangerang Selatan. Sehingga memudahkan kami melakukan koordinasi dengan pihak sekolah dan Universitas Pamulang.

\section{Tahap Pelaksanaan}

Tahap Pelaksanaan pengabdian kepada masyarakat di SMPN 12 Tangerang Selatan penentuannya dengan cara melakukan rapat koordinasi dengan pihak sekolah melalui whatsapp dan rapat online dengan zoom.us. Hal ini untuk meminimalisir penyebaran covid-19 dan mengikuti peraturan pemerintah daerah dengan adanya Pembatasan Sosial Berskala Besar (PSBB) di daerah Tangerang Selatan. Dari hasil rapat koordinasi antara anggota dosen Universitas Pamulang dengan pihak sekolah diputuskan pelaksanaan setelah PSBB di Tangerang Selatan yaitu pada tanggal 21 s.d 23 November 2020 dengan mengikuti protokol kesehatan dengan menggunakan Masker, Menjaga Jarak dan Menjaga Kebersihan (3M). Dalam menentukan tanggal pelaksanana kami berkoordinasi dengan pihak sekolah yang memungkinkan tenaga pendidik bisa ikut dalam pelatihan dan penyuluhan tersebut dari awal sampai akhir. Sehingga bisa sesuai dengan target yang kami inginkan yaitu mengetahui mengenai motivasi pembelajaran secara daring dan menambah khazanah ilmu kewirausahaan.

3. Tahap Pelatihan

Pada tahap ini yaitu akan diadakan pelatihan bagaimana cara memberikan motivasi kepada para tenaga pendidik dalam proses pembelajaran. Adapun yang akan diberikan berdasarkan pengalaman para dosen dalam mengimplementasikan di kelas bersama mahasiswanya maupun di luar kelas. Sehingga ilmu yang diberikan dapat terserap dan bermanfaat bagi mahasiswa dan masyarakat.

\section{HASIL DAN PEMBAHASAN}

\section{Pembelajaran Online}

\section{Pengertian Pembelajaran Online}

Dewasa ini perkembangan teknologi informasi dan komunikasi telah berkembang sangat pesat sehingga mendorong berkembangnya berbagai lembaga pendidikan yang memanfaatkan pembelajaran online untuk meningkatkan efektivitas dan fleksibilitas belajar. Melalui pembelajaran online materi belajar dapat diakses di mana saja dan kapan saja. Disamping itu, materi belajar dapat diperkaya dengan berbagai sumber pembelajaran termasuk multimedia (Wulandari \& Noveandini, 2010). Pembelajaran online dilakukan dengan memanfaatkan teknologi khususnya internet. Pembelajaran online dilakukan dengan sistem belajar jarak jauh, dimana Kegiatan Belajar dan Mengajar (KBM) tidak dilakukan secara tatap muka. Pembelajaran dilakukan dengan menggunakan media, baik media cetak (modul) maupun non cetak (audio/video), komputer/internet, siaran radio dan televisi (Mona, 2020).

\section{Dampak Pembelajaran Online}

Melakukan pembelajaran online memiliki beberapa dampak positif dalam pembelajaran online, antara lain (Wulandari \& Noveandini, 2010):

a. Meningkatkan interaksi belajar antara pembelajar dengan pengajar (enhance interactivity).

b. Memungkinkan belajar dimana saja dan kapan saja (time and place flexibility). 
c. Menjangkau peserta didik dalam cakupan yang luas (potential to reach a global audience).

d. Mempermudah penyimpanan dan penyempurnaan dalam belajar (easy updating of content as well as archivable capabilities).

e. Membangun Komunitas.

3. Komponen Pembelajaran Online

Pembelajaran Online memiliki tiga komponen yang membentuk Pembelajaran Online, antara lain; (Wulandari \& Noveandini, 2010)

a. Fasilitas Pembelajaran Online Fasilitas yang menunjang pembelajaran online dapat berupa internet, smartphone, personal computer (PC), jaringan computer dan perlengkapan multimedia lainnya.

b. Sistem dan Aplikasi Pembelajaran Online Sistem perangkat lunak yang menunjang untuk proses pembelaharan online, seperti bagaimana membuat materi belajar atau konten belajar, forum diskusi dan segala fitur yang berhubungan dengan mempermudah proses belajar mengajar.

c. Materi Pembelajaran Online Konten dan bahan belajar pada pembelajaran online dapat berupa Multimedia-based Content atau konten berbentuk multimedia interaktif seperti video pembelajaran atau Text-based Content atau konten berbentuk teks seperti pada buku pelajaran biasa.

\section{Motivasi Belajar}

\section{Pengertian Motivasi Belajar}

Motivasi berasal Bahasa latin yaitu kata movere yang memiliki arti dorongan di dalam diri seseorang untuk dapat bertindak sehingga mencapai tujuan tertentu. Motivasi adalah hasrat, dorongan dan kebutuhan seseorang untuk dapat melakukan aktivitas tertentu. Sehingga motivasi diartikan sebagai kekuatan yang mendorong tindakan menuju suatu tujuan (Cleopatra, 2015).

Motivasi belajar dalam diri seseorang akan menimbulkan gairah atau meningkatkan semangat dalam belajar. Motivasi belajar mengandung usaha untuk mencapai tujuan belajar yaitu pemahaman materi dan pengembangan belajar. Selain itu, motivasi belajar adalah sebuah penggerak atau pendorong yang membuat seseorang akan tertarik kepada belajar sehingga akan belajar secara terus-menerus (Novianti, 2011).

Motivasi belajar yang rendah dapat menimbulkan dampak negatif bagi siswa, Motivasi belajar yang rendah dapat menyebabkan rendahnya keberhasilan dalam belajar sehingga akan merendahkan prestasi belajar siswa (Raimbarizki, 2017).

Motivasi belajar dalam diri siswa satu dengan siswa yang lain berbeda, ada siswa yang memiliki motivasi belajar tinggi dan ada juga siswa yang memiliki motivasi belajar rendah (Surjono \& Wulandari, 2013).

2. Dampak Motivasi Belajar yang Rendah

Motivasi belajar yang rendah dapat menyebabkan rendahnya keberhasilan belajar siswa. Lemahnya motivasi belajar akan melemahkan prestasi belajar dan melemahnya kegiatan belajar. Peserta didik yang kurang memiliki motivasi belajar ditandai dengan (Raimbarizki, 2017): a. Tidak antusias dalam belajar; b. Lebih senang berada diluar kelas atau membolos; c. Cepat merasa bosan; d. Mengantuk; e. Pasif.

\section{Indikator Tingkat Motivasi Belajar pada Siswa}

Dalam mengetahui tingkat motivasi belajar pada siswa terdapat beberapa indikator motivasi belajar siswa meliputi (Surjono \& Wulandari, 2013):
a. Ketekunan dalam belajar
b. Minat dan ketajaman perhatian dalam belajar
c. Ulet dalam menghadapi kesulitan
d. Mandiri dalam belajar
e. Keinginan berhasil dalam belajar
f. Reward/pujian/penghargaan.

4. Komponen Motivasi Belajar

Ada tiga komponen pada motivasi belajar, yaitu (Novianti, 2011):

a. Komponen Harapan 
Harapan dengan keyakinan diri siswa mengenai kemampuan siswa dalam memahami materi belajar dan dalam mengerjakan tugas.

b. Komponen Nilai

Komponen nilai mencakup tujuan belajar siswa dan kepercayaan tentang arti belajar dan arti mengerjakan tugas.

c. Komponen Afektif

Komponen afektif berhubungan terhadap reaksi emosional siswa ketika siswa menghadapi tugas dan pembelajaran.

Menjadi tenaga pendidik bukan hanya di dalam kelas, tetapi juga di luar kelas. Hal ini sangat dibutuhkan sesuai dengan peraturan pemerintah mengenai Standar Nasional Pendidikan dan disesuaikan juga dengan Standar Tenaga Pendidik dan Pendidik.

Standar Tenaga Pendidik yaitu:

1. Kompetensi pedagogik

2. Kompetensi Kepribadian

3. Kompetensi Profesional; dan

4. Kompetensi Sosial

Ke empat standar tersebut harus dipenuhi oleh tenaga pendidik sehingga capain pembelajaran dan lulusan sesuai dengan yang diharapkan. Selain itu, dibutuhkan ilmu kewirausahaan sesuai dengan yang diajarkan baginda Rasulullah SAW yang memiliki sifat sidiq, tabligh, fatonah, amanah. Sehingga diberikan kemudahan dalam menjalankan aktivitas sebagai tenaga pendidik dan membuka usaha dengan cara yang halal dan thoyib. Dengan ilmu yang dimiliki dari beberapa dosen Universitas Pamulang maka diberikan pelatihan mengenai motivasi pembelajaran secara daring dan persiapan pembelajaran luring serta memberikan ilmu mengenai bagaimana cara bertahan hidup di masa Pandemi Covid-19.

Hal ini membantu merangsang para tenaga pendidik untuk memberikan pendidikan yang langsung terimplementasi di masyarakat. Sehingga tidak hanya teori tetapi juga ada implementasinya dan evaluasinya. Dengan keilmuan yang dimiliki dari dosen program studi manajemen menjadikan kami bisa mentransfer ilmu yang kami miliki untuk diberikan kepada para tenaga pendidik di SMPN 12 Tangsel. Tema yang kami ajukan ini sangat diapresiasi dan diharapkan oleh pihak sekolah sehingga dibutuhkan persiapan, dana serta materi untuk pelatihan dan penyuluhan di acara Pengabdian Kepada Masyarakat di SMPN 12 Tangsel.

Dengan metode pemberian motivasi secara langsung dengan jarak 1,5 meter per orang dengan ruangan 3 kelas dijadikan 1 kelas diisi oleh sekitar 30 tenaga pendidik dengan beberapa narasumber. Pengabdian Kepada Masyarakat pada Semester Ganjil Tahun Akademik 2020/2021 sasarananya adalah tenaga pendidik di SMPN 12 Tangerang Selatan. Sebelum menentukan sasaran tersebut, kami melakukan survey melalui wawancara dan data dari Wakil Kepala SMPN 12 Tangerang Selatan.

Setelah mendapatkan informasi dari Wakil Kepala SMPN 12 Tangerang Selatan bahwa ada sekitar 50 tenaga pendidik yang akan mengikuti pelatihan, dikarenakan adanya Pandemi Covid-19 jadi peserta pelatihan dibatasi hanya 30 orang. Dari Universitas Pamulang diketuai oleh Syarifah Ida Farida, S.E., M.M. dan dibantu oleh dosen lainnya yaitu Teguh Yuwono, S.S., M.M., Yusep Prihanto, S.Pd., M.Pd., R.Chepi Safei Jumhana,S.S.i, M.M, dan Lucia Maduningtias, ST, M.M., serta beberapa mahasiswa. Kepala Sekolah serta Wakil Kepala Sekolah dan seluruh peserta pelatihan yaitu Tenaga Pendidik SMPN 12 Tangerang Selatan hadir dalam acara Pengabdian Kepada Masyarakat. Tempat pelaksanaan kegiatan Pengabdian Kepada Masyarakat yang kami lakukan bekerjasama dengan SMPN 12 Tangerang Selatan yang beralamat di Jl. Jurang Mangu Bar. No.62, Jurang Mangu Barat, Kec. Pd. Aren, Kota Tangerang Selatan, Banten 15222. Adapun acara tersebut terselenggara dari Tanggal 21 - 23 November 2020 di SMPN 12 Tangerang Selatan.

\section{Tahap Persiapan}

a. Survey Awal

Kami melakukan survey ke SMPN 12 Tangerang Selatan dipandu oleh pimpinan di sana untuk mengetahui bagaimana fasilitas dan jumlah dari tenaga pendidik di sana. survei kami lakukan pada bulan September 2020 melalui kerjasama dengan pihak sekolah yang diwakili oleh Wakil Kepala Sekolah yaitu Ibu Hanum. 
Informasi yang kami butuhkan bisa kami dapatkan melalui ibu Hanum dan diberikan sesuai dengan data yang dibutuhkan.

b. Pemantapan dan penentuan lokasi dan sasaran

Setelah melakukan survey dan mendapatkan informasi serta data dari pihak SMPN 12 Tangerang Selatan, maka kami menentukan waktu dan tema yang sesuai kebutuhan dari pihak sekolah.

Adapun sasaran yang kami tentukan untuk Pengabdian Kepada Masyarakat di SMPN 12 Tangerang Selatan yaitu Tenaga Pendidik sebanyak 25 dikarenakan adanya pandemi covid-19 jadi kami batasi menjadi 25 tenaga pendidik dengan mengikuti protokol kesehatan. Sedangkan sebenarnya total keseluruhan tenaga pendidik ada 50 orang.

Kami mendapatkan lokasi Pengabdian Kepada Masyarakat ini dikarenakan permintaan dari pihak sekolah untuk memotivasi tenaga pendidik di SMPN 12 Tangerang Selatan. Hal ini yang membuat kami termotivasi dalam mempersiapkan Pengabdian Kepada Masyarakat di SMPN 12 Tangerang Selatan.

Selain itu, jarak tempat Pengabdian Kepada Masyarakat ini juga dekat dengan Universitas Pamulang yang terletak di Jurang Mangu Tangerang Selatan. Sehingga memudahkan kami melakukan koordinasi dengan pihak sekolah dan Universitas Pamulang. Semoga bisa terus berkelanjutan kerjasama Universitas Pamulang dengan Sekolah Menengah Pertama Negeri 12 Tangerang Selatan dalam melakukan kegiatan tridharma perguruan tinggi dan kegiatan lainnya yang positif dan bermanfaat.

\section{Tahap Pelaksanaan Pengabdian Kepada Masyarakat}

Tahap Pelaksanaan pengabdian kepada masyarakat di SMPN 12 Tangerang Selatan penentuannya dengan cara melakukan rapat koordinasi dengan pihak sekolah melalui whatsapp dan rapat online dengan zoom.us. Hal ini untuk meminimalisir penyebaran covid-19 dan mengikuti peraturan pemerintah daerah dengan adanya Pembatasan Sosial Berskala Besar (PSBB) di daerah Tangerang Selatan. Dari hasil rapat koordinasi antara anggota dosen Universitas Pamulang dengan pihak sekolah diputuskan pelaksanaan setelah PSBB di Tangerang Selatan yaitu pada tanggal 21 s.d 23 November 2020 dengan mengikuti protokol kesehatan dengan menggunakan Masker, Menjaga Jarak dan Menjaga Kebersihan (3M).

Dalam menentukan tanggal pelaksanana kami berkoordinasi dengan pihak sekolah yang memungkinkan tenaga pendidik bisa ikut dalam pelatihan dan penyuluhan tersebut dari awal sampai akhir. Sehingga bisa sesuai dengan target yang kami inginkan yaitu mengetahui mengenai motivasi pembelajaran secara daring dan menambah khazanah ilmu kewirausahaan.

\section{Tahap Pelatihan}

Pelatihan Motivasi Pembelajaran Daring disampaikan oleh Teguh Yuwono, S.S., M.M., C.T., CH., CHt. melalui Character Building Through Capacity \& Capability for Resources Education di SMPN 12 Tangerang Selatan.

Tahap awal yaitu Test Fokus: Follow, One, Course, Until, Succesfull

Memberikan tes fokus kepada tenaga pendidik melalui metode tangan ke kepala dan dagu. Siapakah yang fokus atau tidak, melalui instruksi yang diberikan. Setelah semua peserta sudah fokus maka dilanjutkan slide berikutnya yaitu Sekolah adalah Miniatur Kehidupan di Masa Depan, Mendidik adalah Kewajiban Setiap Orang Terdidik. Ruang Kerja Pendidik yaitu Guru, Dosen dan lain-lain atau ruang kerja kita semua sejatinya bukanlah di kelas-kelas. Orang yang dapat meraih masa depan, bukanlah orang yang tinggi, besar, kokoh dan kuat, namun yang mampu beradaptasi.

Yang perlu diingat yaitu dalam memberikan teladan untuk diri sendiri dan orang lain adalah:

1. Sikap: Menentukan detik berikutnya dalam kehidupan kita

2. Masalahnya. Bukan terletak dari masalah yang kita hadapi, namun sikap kita dalam menghadapi masalah.

Selain itu, pelatih memberikan contoh Kisah Inspiratif: Kisah Ikan Salmon: Bergerak atau Mati!!; Kisah Bebek dan Ayam; Berpikir Out Of The Box; Helicopter View; Kaya Akan Interpretasi.

Anak yang cerdas adalah anak yang memiliki kreativitas dan mampu menyelesaikan masalahnya sendiri. Sumber Daya Manusia yaitu salah satunya adalah pendidik harus memiliki Kompetensi: 
1) Attitude Competence

2) Knowledge Competence

3) Skill Competence

4) Experince Competence

Proyeksi Pendidikan di Masa Depan:

a. Karakter:

1) Karakter Moral (Iman, Taqwa, Jujur dsb)

2) Karakter Kinerja (Disiplin, Kerja Keras, dsb)

b. Kompetensi: Kritis, Kreatif, Komunikatif, Kolaboratif

c. Literasi (Keterbukaan wawasan):

Baca - budaya - teknologi - keuangan

Dalam pembuatan pengajaran Daring yaitu:

1) Buat paparan yang menarik dan mudah dipahami

2) Selingi motivasi (kata, kalimat, visualisasi)

3. Buat kata-kata yang inspiratif: Transformasi, Demonstrasi, Motivasi, Inspirasi

Dari pohon mangga jangan diminta berbuah durian, tetap jadikan setiap pohon menghasilkan buah yang manis.

Teguh Yuwono selalu narasumber memaparkan bahwa hakekat ruang kerja guru itu bukanlah di kelas-kelas, namun di alam pikiran dan hatinya. Maka ketika metode pengajaran berubah tidak bisa tatap muka di kelas dikarenakan pandemi, mestinya ada perenungan dan pemikiran menciptakan metode yang mampu menggerakkan anak didik untuk tetap belajar. Guru tidaklah menciptakan produk, namun menciptakan pengaruh terhadap murid-muridnya.

Disinilah pentingnya kemampuan komunikasi melalui tulisan dan visualisasi baik video maupun voice noted atau sekedar tulisan untuk dibaca. Guru perlu menguasai kata-kata "magic" yang dimata muridnya itu "wow", sehingga mampu memotivasi dan menginspirasi. Seperti kata-kata : " kalian tidak salah, dilahirkan dari keluarga yang bodoh !!. Kalian tidak salah dilahirkan dari lingkungan yang bodoh!! Tapi salah besarrrr kalau kalian tetap tidur dalam kubangan kebodohan..... ! Maka, ketika kalian belajar dengan sungguh-sungguh, artinya kalian sedang memutus rantai kebodohan di lingkungan kalian".

Sesi dialog makin hangat ketika salah satu guru olah raga bertanya dengan nada agak stress (curhat), metode seperti apa yang harus diajarkan kepada murid-muridnya melalui daring untuk bidang olah raga? disertai tawa renyah para peserta. Guru itu ibarat dalang, tidak akan kehabisan lakon atau cara, begitu penjelasan Teguh sambil menjelaskan demo-demo kecil bagaimana merubah sudut pandang dengan sulap kartu. Lalu tanpa disadari, guru olah raga itu didekati dan diajak bicara pelan dari hati ke hati dengan seksama. Dan tiba-tiba saja guru tersebut terkantuk dan diasupi sugesti motivasi agar yakin, percaya diri dan mampu mengajar olah raga meski melalui daring dan zoom. Sesi diakhiri foto bersama dan pemberian doorprize buku tulisan narasumber "Journey To Wisdom" yang diterbitkan oleh Gramedia.

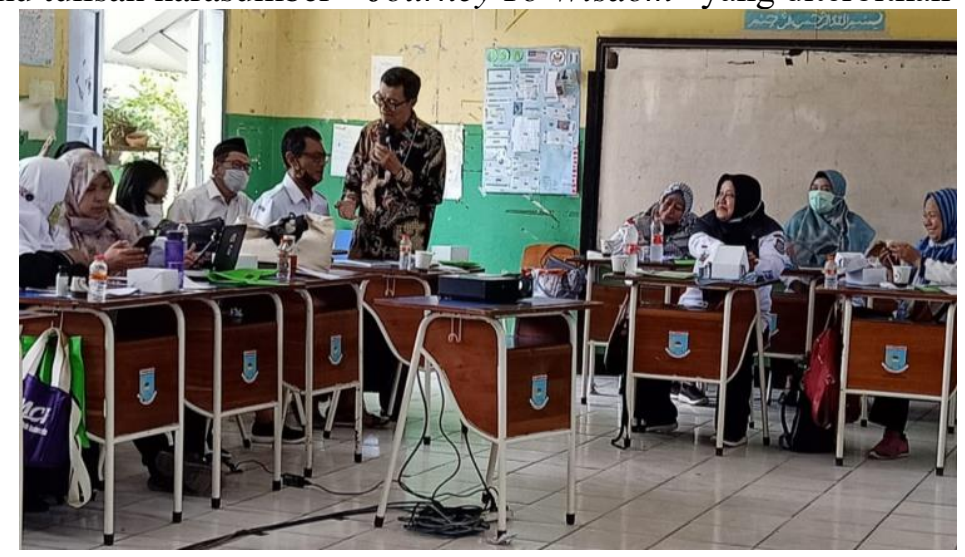

Gambar 1. Sesi Dialog Narasumber dengan Tenaga Pendidik di SMPN 12 Tangerang Selatan Bertahan Hidup Di Masa Pandemi Covid-19

Sesi berikutnya disampaikan oleh Ketua Pengabdian Kepada Masyarakat yaitu Syarifah Ida Farida, S.E., M.M.. Setiap manusia di dunia ini sudah ditentukan takdirnya baik takdir yang bisa 
dirubah maupun tidak bisa dirubah. Kematian merupakan takdir yang tidak bisa dirubah oleh manusia. Sedangkan rezeki, jabatan, kesehatan, kecerdasan, kejujuran dan kepemimpinan dalam diri kita semua bisa dirubah menjadi lebih baik lagi asalkan kita selalu menjalankan perintah Allah SWT dan menjauhi larangan-Nya.

Manusia merupakan makhluk ciptaan Allah SWT yang paling mulia, dikarenakan diberikan akal yang tidak dimiliki makhluk lainnya. Oleh karena itu, sepatutnya kita semua bersyukur atas karunia dan rahmat yang diberikan dari Sang Pencipta dengan cara mempergunakan otak yang telah diberikan. Tidak ada manusia yang bodoh dan pemalas, yang ada hanya mereka kurang termotivasi dalam melakukan suatu aktivitas atau kegiatan. Motivasi setiap manusia berbeda-beda, ada yang ingin menjadi orang sukses, orang kaya, jabatan tinggi, tetapi itu semua bisa didapatkan dengan cara berdoa dan berusaha dengan semaksimal mungkin menjadi manusia yang bermanfaat bagi orang lain dan alam semesta (Ahidin dkk, 2020).

Semenjak adanya COVID-19 yang merupakan penyakit menular disebabkan oleh Virus bernama SARS-COV-2, atau seringkali disebut Virus Corona yang pertama kali berasal dari Wuhan China di akhir tahun 2019 semua kehidupan manusia berubah 180 derajat. Penyebaran Covid-19 yang bersifat luar biasa dengan ditandai jumlah kasus dan/atau jumlah kematian telah meningkat dan meluas lintas wilayah dan lintas negara dan berdampak pada aspek politik, ekonomi, sosial, budaya, pariwisata, hukum, pertahanan dan keamanan, serta kesejahteraan masyarakat di Indonesia, maka Presiden mengeluarkan Peraturan Pemerintah Republik Indonesia Nomor 21 Tahun 2020, tentang Pembatasan Sosial Berskala Besar Dalam Rangka Percepatan Penanganan Corona Virus Disease 2019 (Covid-19).

Ada beberapa cara yang bisa dan harus dilakukan untuk semua umat manusia baik di masa Pandemi Covid-19 maupun setelahnya, diantaranya sebagai berikut: (Farida, 2020)

\section{Berdoa}

Semua yang kita lakukan dimulai dari membaca Bismillah dengan berdoa kepada Allah SWT. Doa adalah salah satu kunci sukses manusia hidup di dunia dan akhirat. Niat kan semua aktivitas yang dilakukan karena Allah SWT dari bangun tidur sampai dengan mau tidur, Insya Allah semuanya dimudahkan dan diberikan keberkahan. Sebagaimana Allah SWT turunkan ayat suci Al Quran Surat Adz Dzariyat ayat 56 yaitu "Dan Aku tidak menciptakan jin dan manusia melainkan supaya mereka beribadah kepada-Ku." Sangat jelas dalam ayat tersebut bahwa manusia di dunia ini diciptakan untuk beribadah kepada Allah SWT.

\section{Motivasi Diri}

Tidak ada manusia yang malas dan bodoh, tetapi adanya manusia yang kurang termotivasi. Semua manusia apabila melakukan sesuatu ada imbalannya pasti akan termotivasi. Contohnya kita hidup untuk beribadah, tujuannya untuk masuk surga. Selain itu, apabila manusia berbuat baik maka akan mendapatkan pahala yang lebih baik, begitu pula balasan yang diterima orang yang berbuat jahat pasti akan mendapatkan balasan yang sama atas apa yang telah diperbuat. Dalam Quran Surat An-Najm ayat 31 bahwa "Supaya Dia memberi balasan kepada orangorang yang berbuat jahat terhadap apa yang telah mereka kerjakan dan memberi balasan kepada orang-orang yang berbuat baik dengan pahala yang lebih baik."

\section{Ikhtiar/Berusaha}

Manusia sudah ditakdirkan rezekinya dan bisa dirubah sesuai dengan usahanya. Seperti yang sudah dijelaskan dalam Quran Surat Ath Thalaq ayat 2 - 3 "Barangsiapa bertakwa kepada Allahniscaya Dia akan mengadakan baginya jalan keluar, dan memberinya rezeki dari arah yang tiada disangka-sangka. Dan barangsiapa yang bertawakal kepada Allah niscaya Allah akan mencukupkan (keperluan)-nya. Sesungguhnya Allah melaksanakan urusan yang (dikehendaki)-Nya. Sesungguhnya Allah telah mengadakan ketentuan bagi tiap-tiap sesuatu."

\section{Silaturahmi}

Silaturahmi merupakan salah satu jalan untuk memperbanyak rezeki dan memperjanjang umur. Memiliki banyak relasi yang bisa membantu baik di dunia dan akhirat merupakan rezeki yang tak terhingga. Untuk itu, terus berusaha menjadi pribadi yang menyenangkan dan saling membantu kepada sesama. Teman yang baik adalah teman yang selalu mendekatkan diri kepada Allah SWT. Di masa pandemi COVID-19 ini tidak menjadi penghalang untuk bersilaturahmi, melainkan ini merupakan waktu yang tepat untuk saling memaafkan dan 
saling memberikan perhatian yang lebih kepada semua umat manusia di dunia. Silaturahmi dalam masa Pandemi COVID-19 bisa melalui online, langsung bertemu dengan mengikuti Protokol Kesehatan dan social distancing.

\section{Sedekah}

Dalam ayat suci Al Quran dijelaskan bahwa sebagian harta yang telah kita dapatkan dari Allah SWT ada bagian milik orang lain "Dan pada harta benda mereka ada hak untuk orang miskin yang meminta, dan orang miskin yang tidak meminta" (QS Adz Dzariyat: 19). Allah SWT juga memerintahkan kepada kita "Berimanlah kepada Allah dan Rasul-Nya, dan nafkahkanlah sebagian dari hartamu yang Allah telah menjadikan kamu menguasainya. Maka orang-orang yang beriman di antara kamu dan menafkahkan (sebagian) dari hartanya memeroleh pahala yang besar" (QS Al Hadid : 7 ).

\section{Ikhlas}

Tahap terakhir adalah dengan cara Ikhlas, setelah semua sudah dilakukan kita tinggal serahkan semua urusan tersebut kepada Allah SWT. Banyak orang yang tidak bisa menerima kenyataan dengan adanya Pandemi COVID-19 ini, diantaranya ada yang kabur dari Rumah Sakit pada saat menjadi Pasien COVID-19, ada juga yang stroke karena tidak bisa menerima kenyataan yang terjadi. Selain itu, ada juga yang tidak mau menerima atas cobaan yang diberikan dengan melakukan perbuatan yang tidak baik dan merugikan diri sendiri serta orang lain. Semua itu karena hatinya tidak percaya kepada Allah SWT. Sedangkan Allah SWT berjanji akan mengabulkan semua doa hamba-Nya Sebagaimana ditegaskan dalam Alquran yang artinya,

Pandemi Covid-19 ini menjadikan manusia lebih peduli akan diri sendiri dan orang lain, menjaga kebersihan serta lebih mendekatkan diri kepada Sang Pencipta. Dengan adanya pandemi Covid-19 ini berimbas dengan kegiatan luring seperti sektor pendidikan, pariwisata, perdagangan, kesehatan dan lain-lain. Pendidikan yang selama ini hampir 100 persen untuk siswa-siswi serta guru-guru atau tenaga pendidik di sekolah maupun di perguruan tinggi melakukan pembelajaran secara luring sebelum adanya pandemi Covid-19. Semenjak adanya Pandemi Covid-19, semua pembelajaran secara daring (online). Hal ini dilakukan pemerintah Indonesia untuk membatasi kegiatan di luar rumah untuk meminimalisir penularan virus Covid-19.

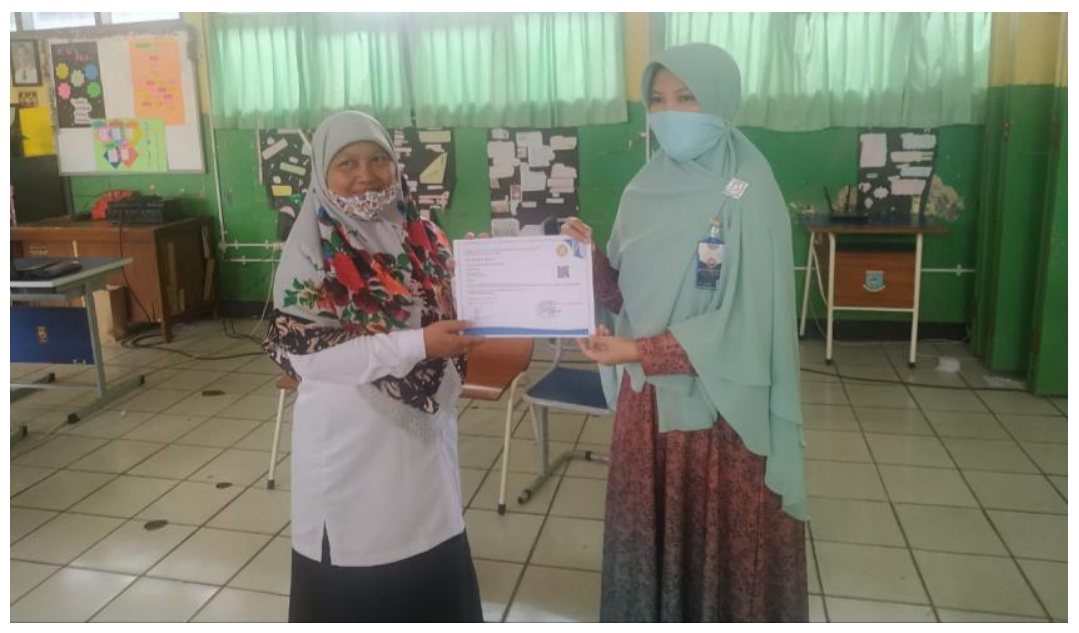

Gambar 2. Pemberian Sertifikat secara simbolis kepada Wakil Kepala SMPN 12 Tangerang Selatan

\section{SIMPULAN}

Pelaksanaan kegiatan Pengabdian Kepada Masyarakat (PKM) yang dilakukan oleh Tim PKM yang terdiri dari Syarifah Ida Farida, S.E., M.M., sebagai Ketua PKM dan didukung oleh dosen UNPAM lainnya yaitu Teguh Yuwono, S.S., M.M., Yusep Prihanto, S.Pd., M.Pd., R.Chepi Safei Jumhana, S.S.i, M.M, dan Lucia Maduningtias, ST, M.M., serta beberapa mahasiswa Universitas Pamulang pada tanggal 21 s.d 23 November 2020 di SMPN 12 Tangerang Selatan. Pelatihan Motivasi Pembelajaran Daring disampaikan oleh Teguh Yuwono, S.S., M.M., C.T., CH., CHt. melalui Character Building Through Capacity \& Capability for Resources Education dan Bertahan Hidup di Masa Pandemi Covid-19. Oleh Syarifah Ida Farida, S.E., M.M. 


\section{SARAN}

Berdasarkan hasil kegiatan Pengabdian Kepada Masyarakat, maka kami dari Tim Dosen Universitas Pamulang memberikan saran diantaranya sebagai berikut:

1. Pelatihan ini sebaiknya juga diberikan kepada para orang tua wali murid, dikarenakan pembelajaran daring lebih banyak bantuan dari pihak keluarga. Baik moril maupun materil, sehingga dibutuhkan motivasi yang tinggi untuk para wali murid.

2. Pemerintah sebaiknya memberikan motivasi baik moril maupun materil untuk para tenaga pendidik dan orang tua, sehingga capaian pembelajaran dan kebutuhan para pendidik dan peserta didik terfasilitasi.

\section{UCAPAN TERIMA KASIH}

Penulis mengucapkan terima kasih kepada Universitas Pamulang yang telah memberi dukungan financial terhadap pengabdian ini.

\section{DAFTAR PUSTAKA}

Ahidin dkk, U. (2020). Covid 19 \& Work From Home. Serang: Desanta Muliavisitama.

Cleopatra, M. (2015). Pengaruh Gaya Hidup dan Motivasi Belajar terhadap Prestasi Belajar Matematika. Formatif: Jurnal Ilmiah Pendidikan MIPA.

Farida, S. I. (2020, Juni 5). rakyatmerdekanews.com. Retrieved from rakyatmerdekanews.com: https://rakyatmerdekanews.com/2020/06/05/cara-bertahan-hidup-di-masa-pandemi-covid$19 /$

Mona, N. (2020). KOnsep Isolasi Dalam Jaringan Sosial Untuk Meninimlisasi Efek Contagious (Kasus Penyebaran Virus Corona di Indonesia). Jurnal Sosial Humaniora Terapan Universitas Indonesia.

Novianti, N. (2011). Kontribusi Pengelolaan Laboratorium dan Motivasi Belajar Siswa terhadap Efektivitas Proses Pembelajaran. Jurnal Pendidikan MIPA Edisi Khusus 1, 158-166.

Raimbarizki, R. (2017). Penerapan Pembelajaran Daring Kombinasi dalam Meningkatkan Motivasi Belajar Peserta Didik Paket C Vokasi di Pusat Kegiatan Belajar Masyarakat (PKBM) Pioneer Karanganyar. J+Plus UNESA.

Surjono, H., \& Wulandari, B. (2013). Pengaruh Problem-Based Learning terhadap Hasil Belajar Ditinjau dari Motivasi Belajar PLC di SMK. . Jurnal Pendidikan Vokasi, 3 (2).

Wulandari, M., \& Noveandini, R. (2010). Pemanfaatan Media Pembelajaran Secara Online (Elearning) Bagi Wanita Karir Dalam Upaya Meningkatkan efektivitas dan Fleksibilitas Pemantauan Kegiatan Belejar Anak Siswa/i Sekolah Dasar. Seminar Nasional Aplikasi Teknologi Informasi (SNATI). 